\title{
An interdisciplinary reflection on the perception of students' environmental education about Pedagogical Practices in Elementary School I of the Padre João D'Vries Municipal School in the city of Manaus
}

\section{Greyce dos Santos Rodrigues ${ }^{1}$, Claudio Alves Nanhum², David do Socorro Barros Brasil ${ }^{3}$}

${ }^{1,2,3}$ Programa de Pós-Graduação em Ciência e Meio Ambiente (PPGMA) do Instituto de Ciências Exatas e Naturais (ICEN) da Universidade Federal do Pará (UFPA). Avenida Augusto Correa 01. Campus Guamá. Belém-PA. Brasil. CEP: 66075-110.

Email: Greyce.gsr@gmail.com; nahum@ufpa.br; dsbbrasil@ig.com.br

\author{
Received: September $02^{\text {th }}, 2017$ \\ Accepted: September $19^{\text {th }}, 2017$ \\ Published: September $30^{\text {th }}, 2017$ \\ Copyright $@ 2016$ by authors and Institute \\ of Technology Galileo of Amazon (ITEGA \\ Commons Attribution International \\ License (CC BY 4.0). \\ http://creativecommons.org/licenses/by/4.0/ \\ cc) (i) (2) Open Acest
}

\begin{abstract}
The present research was carried out in a municipal school located in the East Zone of Manaus, with the objective of proposing an interdisciplinary reflection on the perception of environmental education in primary school. Among the activities developed are the application of questionnaires, lectures and arts through figures. The research questionnaire was applied to the universe of 66 students of both sexes with ages between 10 to 13 years and 8 teachers. The lectures held mainly . cover topics related to awareness of the importance of environmental conservation, firefighting and environmental pollution control. The workshops allowed the free expression of the students to show through the drawings their conceptions about environmental perception. All the activities developed in this project allowed mobilizations to improve pedagogical practices, seeking participatory actions students-teachers-community with the objective of raising awareness and reflecting on environmental issues.
\end{abstract}

Keywords: Environmental education. Environmental Perception. Pedagogical practices.
Uma reflexão interdisciplinar sobre a percepção da educação ambiental dos alunos sobre as Práticas Pedagógicas no Ensino Fundamental I da Escola Municipal Padre João D’vries no município de Manaus

\begin{abstract}
RESUMO
A presente pesquisa foi realizada em uma escola municipal localizada na Zona Leste de Manaus, com o objetivo de propor uma reflexão interdisciplinar sobre a percepção da educação ambiental na escola primária. Entre as atividades desenvolvidas estão a aplicação de questionários, palestras e artes através de desenhos. O questionário de pesquisa foi aplicado ao universo de 66 alunos de ambos os sexos com idades entre 10 a 13 anos e 8 professores. As palestras realizadas principalmente cobrem tópicos relacionados à conscientização sobre a importância da conservação ambiental, combate a incêndio e controle de poluição ambiental. As oficinas permitiram a livre expressão dos alunos para mostrar através dos desenhos suas concepções sobre percepção ambiental. Todas as atividades desenvolvidas neste projeto permitiram mobilizações para melhorar as práticas pedagógicas, buscando ações participativas estudantes-professores-comunidade buscando a sensibilização nas reflexões ambientais.
\end{abstract}

Palavras-chave: Educação Ambiental. Percepção Ambiental. Práticas Pedagógicas.

\section{INTRODUÇÃO}

A presente pesquisa vem contribuir de forma significativa sobre as práticas pedagógicas de ensino voltado para ao meio ambiente. Apresenta-se uma pesquisa realizada em uma escola Municipal localizado na Zona Leste de Manaus objetivando propor uma reflexão interdisciplinar sobre a percepção da educação ambiental no ensino fundamental I, voltada às práticas pedagógicas no que concerne a sensibilização, conscientização e conservação para o desenvolvimento da transformação social ambiental. 
A Educação Ambiental está alicerçada na Lei 9.795/99, em seu art. $2^{\circ}$, estabelece que a Educação Ambiental, está presente, de modo formal articulada, em todos os níveis e modalidade do processo educativo, em caráter formal.

A pesquisa trata-se uma análise perceptiva dos alunos e professores sobre as práticas pedagógicas de ensino, relacionadas à educação ambiental formal. De acordo com a política nacional de educação ambiental na Lei 9795/99 em seu Art. $1^{\circ}$ compreende-se por educação ambiental:

A Educação ambiental permite que o indivíduo e a coletividade construam valores sociais, por meio dos conhecimentos, habilidades, atitudes e competências voltadas para a conservação do meio ambiente, do uso comum do povo, essencial à sadia qualidade de vida e sua sustentabilidade.

Para tanto a interdisciplinaridade é um componente curricular essencial e permanente para integração da base da educação nacional. Alicerçada na Lei no 9795/99 que em seu Art. 10 comenta que a educação ambiental é como uma prática educativa integradora, contínua e permanente em todos os níveis e modalidades do ensino formal.

De maneira que articulando as práticas pedagógicas com o meio ambiente os discente desenvolveram uma efetiva sensibilização, conscientização e principalmente a conservação para o cuidado com meio ambiente.

Haja vista que no cenário atual, vive-se em um mundo, não preocupado o suficiente em questões voltadas ao Meio Ambiente. É com essa finalidade que se busca desenvolver a educação ambiental com os alunos e juntamente com a comunidade.

E por meio das práticas pedagógicas busca-se contribuir para a redução dos índices de desmatamento e queimadas que são considerados grandes problemas ecológicos enfrentados na atualidade. E esta inquietação partiu da necessidade de reduzir esse índice principalmente por apresentarem uma cultura de queima muito comum no entorno da escola.

De acordo com a pesquisa o período de queimadas na Amazônia acorrem principalmente no período do verão, onde o clima fica seco e propício à cultura da queima de floresta para efetuar a plantação. em grande porte. Com isso os maiores prejudicados são as comunidades ao seu entorno que com o alto índice de fumaça.

Busca-se por meio das práticas pedagógica ambientais combater a cultura da queimada, principalmente na comunidade, incentivando a conservação do meio ambiente dando ênfase a prática pedagógica. Para incentivar a cultura da conservação e preservação ambiental, humanitária não desperdiçando os conhecimentos adquiridos exercendo corretamente sua cidadania

\section{REVISÃO BIBLIOGRÁFICA}

\section{II.1 EDUCAÇÃO AMBIENTAL}

A educação ambiental é uma das ferramentas existentes para a sensibilização e capacitação da população em geral sobre os problemas ambientais. Com ela, busca-se desenvolver técnicas e métodos que facilitem o processo de tomada de consciência sobre a gravidade dos problemas ambientais e a necessidade urgente de nos debruçarmos seriamente sobre eles [3].

A educação ambiental tem como finalidade proporcionar a todos a possibilidade de adquirir novos conhecimentos, no sentido dos valores, quantos aos interesses ativo e as atitudes necessárias para proteger e melhorar o meio ambiente. Haja vista a transformação de conduta dos indivíduos, nos grupos sociais e na sociedade em respeito ao meio ambiente.
A educação ambiental institui-se política nacional para educação ambiental por meio da Lei 9.795 em 27 de abril de 1999.

A priori a definição da educação como ambiental é relevante, mas também insuficiente se queremos avançar na construção de uma práxis transformadora, uma prática fundamenta em ação educativa onde pretende-se transformar a sociedade [4]

Nesse sentido cabe destacar que a educação ambiental assume cada vez mais uma função transformadora, na qual a coresponsabilização dos indivíduos torna-se um objetivo essencial para promover um novo tipo de desenvolvimento sustentável.

Entende-se, portanto, que a educação ambiental é condição necessária para modificar um quadro de crescente degradação socioambiental, mas ela ainda não é suficiente, e se converte em "mais uma ferramenta de mediação necessária entre culturas, comportamentos diferenciados e interesses de grupos sociais para a construção das transformações desejadas”.

O educador tem a função de mediador na construção de referenciais ambientais e deve saber usá-los como instrumentos para o desenvolvimento de uma prática social centrada no conceito da natureza [5][6].

\section{II.2 PCNS E SUA INTERDISCIPLINARIDADE NA QUESTÃO AMBIENTAL}

A Educação Ambiental foi instituída por meio da Lei n. ${ }^{\circ}$ 9.795/1999, que visa estabelecer a educação ambiental como uma prática educativa integradora, contínua e permanente e de forma transversal e interdisciplinar.

Em seu Art. 10. A educação ambiental será desenvolvida como uma prática educativa integrada, contínua e permanente em todos os níveis e modalidades do ensino formal. $\S 1^{\circ}$. A educação ambiental não deve ser implantada como disciplina específica no currículo de ensino.

De acordo com os Parâmetros Curriculares Nacionais PCN a Educação Ambiental apresenta-se como uma temática a ser inserida no currículo de modo diferenciado, não se configurando como uma nova disciplina, mas por meio da transversalidade.

Os conteúdos de Meio Ambiente serão integrados ao currículo através da transversalidade, pois serão tratados nas diversas áreas do conhecimento, de modo a impregnar toda a prática educativa e, ao mesmo tempo, criar uma visão global e abrangente da questão ambiental. As áreas de Ciências Naturais, História e Geografia serão as principais parceiras para o desenvolvimento dos conteúdos aqui relacionados, pela própria natureza dos seus objetos de estudo. As áreas de Língua Portuguesa, Matemática, Educação Física e Arte ganham importância fundamental por constituírem instrumentos básicos para que o aluno possa conduzir o seu processo de construção do conhecimento sobre meio ambiente. [7][8].

Desse modo de acordo com os PCN's o enfrentamento dos problemas ambientais exige que a educação seja mediadora, articulando teoria e principalmente práticas pedagógicas de ensino. Indubitavelmente a Educação Ambiental, perpassa todas as áreas do conhecimento e exige reflexões acerca da problemática ambiental na qual os conhecimentos dialogam uns com os outros para a formação de cidadãos conscientes, aptos para decidirem e atuarem na realidade socioambiental de um modo comprometido com a vida, com o bem-estar de cada um e da sociedade, local e global.

O trabalho de Educação Ambiental deve ser desenvolvido a fim de ajudar os alunos a construírem uma 
consciência global das questões relativas ao meio para que possam assumir posições afinadas com os valores referentes à sua proteção e melhoria.

De acordo com a teoria da complexidade na educação o pensamento complexo consiste na complexidade do ser e do saber [9].

Entretanto, para articular e organizar os conhecimentos e assim reconhecer e conhecer os problemas do mundo é necessário à reforma do pensamento. Para tanto esta reforma é paradigmática que se entende como algo influenciador de como observamos o mundo, como nos comportamos, nos relacionamos com as pessoas, e não programática que compreende-se por meio de uma lista das matérias, disciplinas e/ou componente curriculares que fazem parte de um curso e/ou que compõem o conteúdo de um concurso é a questão fundamental da educação já que se refere à nossa aptidão para organizar o conhecimento [10] e [11].

A educação ambiental enquanto saber ambiental ultrapassa as "ciências ambientais" para uma nova abertura de valores éticos dos conhecimentos práticos e dos saberes tradicional. Esse novo saber emerge como espaço onde se articulam a natureza, por meio de um processo de reconstituição de identidades resultantes da hibridação entre o material e o simbólico; se produz no entrecruzamento de saberes e se arraiga em novas identidades; emerge, portanto, como complexidade ambiental [12], [13] .

Na qual implica, primeiramente, na desconstrução do pensamento disciplinar, simplificador, unitário para, após, viabilizar as categorias que permitem pensar a inteligibilidade em movimentos dialógicos entre a ordem, a desordem e a organização, por via de inúmeras inter-retroações, ou seja, retornar a uma circunstância anterior ao momento presente reintroduzindo o conhecido em todo o conhecimento.

\section{II.3 PERCEPÇÃO AMBIENTAL NO CONTEXTO ESCOLAR}

A percepção ambiental pode ser definida como sendo uma tomada de consciência do ambiente pelo homem, ou seja, o ato de perceber o ambiente que se está inserido, aprendendo a proteger e a cuidar do mesmo [14].

A percepção está direcionada com o desenvolvimento dos nossos sentidos, que exige que o indivíduo participe desse processo. Por outro lado o professor deverá propiciar uma atividade perceptiva para que o aluno fortaleça e se exercite dentro do ambiente escolar. Por meio de atividades que permitam ao aluno a comunicação e o desenvolvimento da percepção com relação a si mesmo e ao mundo que o rodeia.

Dentro deste contexto compreende-se a percepção como "Uma atividade, um estender-se para o mundo. Os órgãos dos sentidos são poucos eficazes quando não são ativamente usados" [15]. A necessidade de comunicação da criança desenvolve-se paralelamente à organização da sua capacidade de percepção e interação do indivíduo com o meio por meio dos órgãos dos sentidos baseada no conhecimento cultural, ético, social e na postura de cada um, de modo que o aluno tenha ópticas perceptivas diferentes sobre um mesmo objeto.

No âmbito escolar a percepção vincula-se de forma em que a criança percebe e adquiri novos conhecimentos no ambiente escolar, conhecimentos esses que será aplicado posteriormente na vida adulta, onde os principais atores deste processo atuam por meio de relacionamento entre professor versus aluno, aluno versus professor e aluno versus aluno na qual torna-se relevante, uma vez que é a partir disto que a criança irá aprimora-se para a vida em sociedade.
Compete ao papel do professor não só mediar o conhecimento, mas vincular o processo de ensino $\mathrm{e}$ aprendizagem para o enfrentamento de um ser capaz de resolver por meio da criticidade e formulação pensamentos próprios conforme a sua subjetividade [16].

Para tanto a Educação Ambiental é uma ferramenta facilitadora para as discussões em relação à compreensão, à percepção e à conexão do homem com o meio ambiente.

Inserida no contexto escolar a Educação Ambiental deve ser abordada e explorada de forma interdisciplinar, possibilitando ao discente o contato constante com o meio ambiente. O contato contínuo e direto desperta nos alunos uma percepção automática da sua relação com o meio ambiente e isto facilita a compreensão da importância na preservação e nas atitudes comportamentais do dia a dia [17].

Entretanto nem sempre o conhecimento do problema ambiental é condição para a mudança de valores em benefício à conservação ambiental, é necessário que as atitudes sejam lembradas e exemplificadas diariamente, é preciso sentimento e conhecimento para sensibilizar tanto na forma individual quanto na forma grupal.

Por isso ações mitigadoras, projetos criativos e atitudes que despertem o interesse dos alunos são essenciais na aplicação de uma efetiva educação ambiental [17].

A Percepção Ambiental nesse contexto contribuirá para a utilização racional, permitindo uma relação harmônica entre os indivíduos e sociedade para com meio ambiente. Para transformação e formação de cidadãos conscientes, preparados para a tomada de decisões e atuando na realidade sócioambiental, com um comprometimento com a vida, o bem estar de cada um e da sociedade [18].

\section{II.4 QUEIMADAS E DESMATAMENTO MORAM AO LADO}

Há necessidade de uma articulação com a produção de reflexão sobre a educação ambiental dentro de um contexto marcado pela degradação permanente do meio ambiente e seu ecossistema, por meio das práticas pedagógicas para reflexão sobre as práticas sociais.

O desmatamento no território brasileiro deu-se início no litoral com a destruição da Mata Atlântica no Nordeste, primeiramente para a extração do Pau-Brasil enviado a Europa para ser usado como madeira e tintura.

$O$ processo de degradação da cobertura vegetal acelerou-se com a introdução da cultura da cana-de-açúcar e, posteriormente, com a criação do gado bovino. Da Mata Atlântica no Nordeste, as frentes de desmatamento dirigiram-se para o sudeste e sul do país encontrando as Matas de Araucárias e a partir de 1980 para o Centro Oeste avançando sobre os Cerrados por meio da expansão da fronteira em grande parte na borda sul da floresta Amazônica [19].

O desmatamento e as queimadas são considerados um dos grandes problemas ecológicos enfrentados pelo país na atualidade. O Brasil apresenta uma das maiores diversidade biológica em sua fauna e flora, e a falta de um direcionamento no que se refere à sensibilização conscientização e conservação ecológica quanto à exploração dos recursos ambientais vem acarretando prejuízos irreparáveis ao meio ambiente.

De acordo com Instituto Nacional de Meteorologia INMET o cartograma da figura 1 mostra o Índice de inflamabilidade por região. 


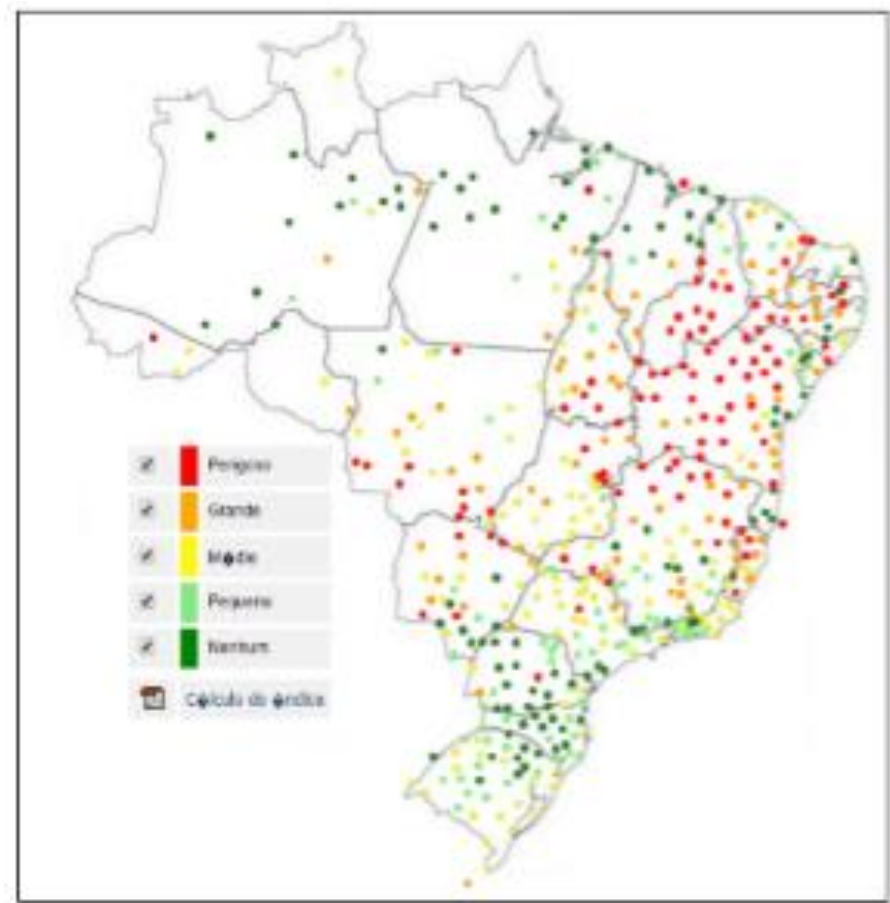

Figura 1: Índice de Inflamabilidade de Nesterov (grau de perigo). Fonte: [28].

No cartograma:

$\checkmark$ Os pontos vermelhos indicam um índice de inflamabilidade perigoso;

$\checkmark$ Os pontos laranja indicam um índice de inflamabilidade grande;

Os pontos amarelos indicam um índice de inflamabilidade médio;

$\checkmark$ Os pontos verdes claro indicam um índice de inflamabilidade pequeno; e

Os pontos verdes escuro indicam nenhum índice de inflamabilidade.

O cartograma da figura 01 mostra que as regiões nordestes, sudeste e centro-oeste apresentam os maiores índices de focos de inflamabilidade no país, sendo mais propicias a incêndios.

Nesse cartograma observa-se que no Norte o índice perigoso de queimadas no Parque Estadual Chandless-AC, Santa Rosa de Tocantins-TO, Peixe-TO, Araguaia-TO, Paraná-TO. Observa-se ainda, algumas áreas classificadas no nível de grande risco de queimadas são Manicoré-AM, Parintins-AM, MarabáPA, Conceição do Araguaia-PA, Santana do Araguaia-PA Vilhena-RO. Níveis médio de risco de incêndio são observados em Boa Vista-RR, Autazes-AM, Rio Branco-AC, EpitaciolandiaAC, Serra dos Xinguara-PA, Cacoal-RO.

\section{II.5 O CONSTRUTIVISMO NA CONCEPÇÃO AMBIENTAL}

A abordagem construtivista na educação ambiental é fundamental para o desenvolvimento cognitivo de qualquer indivíduo. Nesta perspectiva a educação ambiental, é de suma relevância para vida da população em geral e fundamental para futuras gerações.

"À medida que a humanidade aumenta sua capacidade de intervir na natureza para satisfação de necessidades e desejos crescentes, surgem tensões e conflitos quanto ao uso do espaço e dos recursos em função da tecnologia disponível” [20].
Por meio da escola a educação ambiental deve ser desenvolvida sob a ótica da construção de representações do meio ambiente que busca no aluno a possibilidade de conscientização com as questões relacionadas ao meio ambiente, nesse contexto é de suma relevância compreender as ações transformadoras na qual estão inseridos.

Para tanto uma das propostas na concepção Freiriana sobre Educação Ambiental, parti do princípio de centrar-se no compromisso de resgatar as origens do povo, a partir do seu contexto mais próximo[21].

A Educação Ambiental é um processo permanente no quais os indivíduos e a comunidade toma consciência do seu meio ambiente e adquirem conhecimentos, habilidades, experiências, valores e a determinação que os tornam capazes de agir, individualmente ou coletivamente, na busca de soluções para os problemas ambientais presentes e futuros [22].

$\mathrm{Na}$ concepção Piateg compreende que o indivíduo constrói os conhecimentos, dando-nos base para compreender o indivíduo constrói seu conhecimento. Dentro desta perspectiva a educação ambiental apresenta-se como uma nova ressignificação que visa à interação social na formação de cidadãos conscientes por meio de uma aprendizagem significativa, haja vista, o que se aprende relaciona-se com o meio, para que os atores deste processo educativo possam fazer a leitura crítica do cotidiano [23].

Para Vygotsky o professor apresenta-se como responsável e norteador na contribuição para a construção dos novos conhecimentos, dentro de uma proposta sociointeracionaista. [24].

A construção do conhecimento e de habilidades dentro das zonas de desenvolvimento proximal, isto é, a condução dos alunos da zona de desenvolvimento real para um possível desenvolvimento potencial ele volta sempre ao papel desempenhado pelo adulto (no caso de um ensino escolar do professor) mostrando a necessidade deste auxílio, pois segundo ele o desenvolvimento consiste em um processo de processo de aprendizagem dos usos das ferramentas intelectuais, pela interação social com outros mais experimentados no uso dessas ferramentas [25], [26].

A Educação Ambiental é uma práxis educativa e social que tem por finalidade a construção de valores, conceitos, habilidades e atitudes que possibilitem o entendimento da realidade de vida e responsável de atores sociais individuais e coletivos no ambiente ([27].

\section{MATERIAIS E MÉTODOS}

\section{III.1 CARATERIZAÇÃO E DESIGNE DA PESQUISA}

O presente estudo trata-se de uma investigação sobre uma reflexão interdisciplinar sobre a percepção da educação ambiental dos alunos voltada às práticas pedagógicas desenvolvidas por meio de palestras, oficinas de desenhos direcionados a temática ambiental com aplicação de questionários estruturados sobre a percepção ambiental dos alunos e professores.

Permite-se priorizar numericamente a frequência e a intensidade da percepção dos comportamentos dos indivíduos quanto à percepção ambiental no universo de 66 alunos da pesquisa em questão.

O desenvolvimento do projeto é apresentado através do fluxograma 1 . 


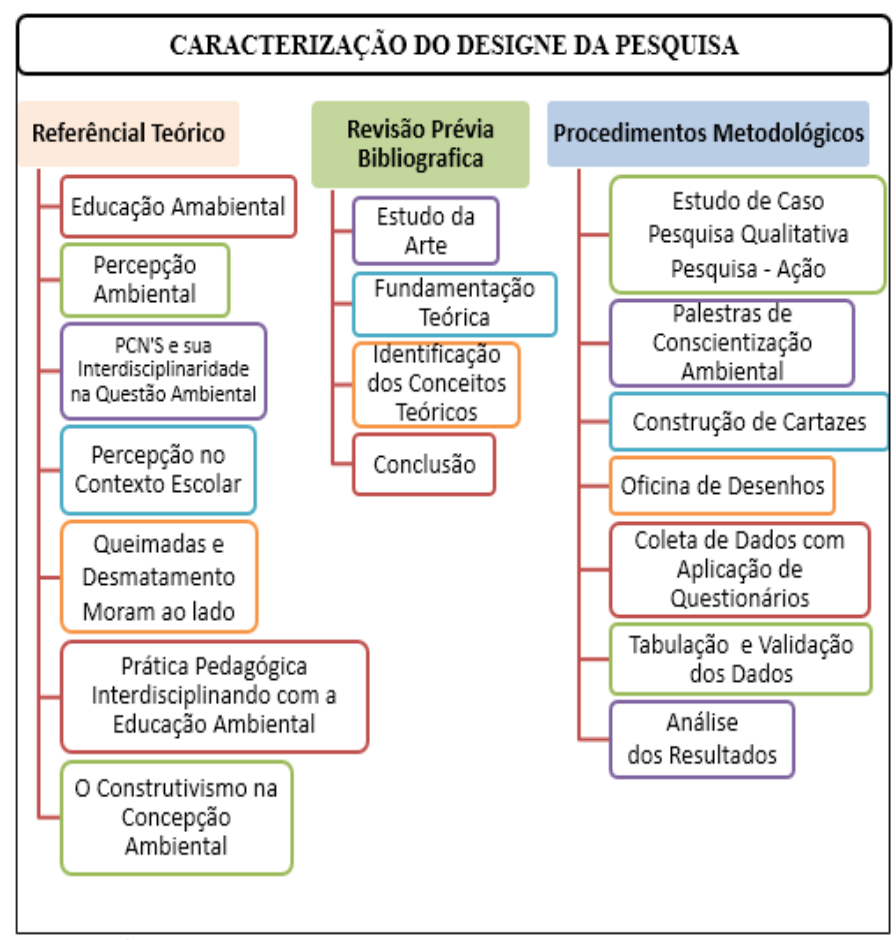

Fluxograma 1: Designe da Pesquisa.

Fonte: Autores, (2017).

\section{III.2 PROCEDIMENTOS METODOLÓGICOS}

Participaram desta pesquisa 66 (sessenta e seis) alunos voluntários de $5^{\circ}$ ano do ensino fundamental da Escola Municipal Padre João D'vries localizado na Zona Leste da cidade de Manaus. A investigação propõe uma reflexão interdisciplinar sobre a percepção da educação ambiental nas práticas pedagógicas no ensino fundamental I.

De acordo com a Resolução do Conselho Nacional de Saúde (CNS) no 510, de 07 de abril de 2016, do Comitê de Ética em Pesquisa Humana, há uma necessidade de incluir os Critérios de Inclusão e Exclusão aos sujeitos da pesquisa participantes, haja vista serem os que possibilitam o estabelecimento do perfil do sujeito participante da pesquisa. Dessa forma, os critérios de inclusão são as condições que fazem com que tal indivíduo seja sujeito participante de uma pesquisa.

Os critérios de exclusão, por sua vez, são aquelas condições que retiraria o sujeito da pesquisa uma vez que este se preenche os critérios de inclusão.

Quanto aos critérios de inclusão:

$\checkmark \quad$ Ser aluno do $5^{\circ}$ ano do ensino fundamental I, da escola em pesquisa;

$\checkmark \quad$ Ser do sexo masculino e feminino;

$\checkmark$ Ser capaz de responder as questões do questionário de pesquisa;

$\checkmark \quad$ Ter faixa etária correspondente entre 10 a 13 anos.

Quanto aos critérios de exclusão:

$\checkmark \quad$ Não conseguir responder as questões do questionário de pesquisa;

$\checkmark \quad$ Ter competência e mínima do processo de escrita;

$\checkmark \quad$ Ter competência e mínima da compreensão do nível alfabético.

De acordo com a Resolução do Conselho Nacional de Saúde (CNS), os critérios servem para um norteamento da pesquisa sendo que o critério de inclusão será o de livre e espontânea vontade na participação da pesquisa e o de exclusão será de desistência de alguns sujeitos.

\section{III.3 ESPECIFICAÇÃO DO PROBLEMA DA PESQUISA}

A problemática ambiental é de cunho social e principalmente educacional e vem superando os âmbitos dos saberes e dos sistemas de conhecimento constituídos permitindo compreender as ações e suas conseqüências produzidas no contexto social, pelo homem no que concerne ao meio ambiente.

Desenvolver nos alunos de modo formal o senso crítico no que tange a conservação para o cuidado com seu próprio meio no qual está inserido e que possam compreender a necessidade da sustentabilidade e como conservar o meio ambiente.

Haja vista na comunidade local apresentar uma cultura de queimada no entorno da escola, a Educação Ambiental é uma ferramenta relevante para mudança de atitudes, comportamentos, pois o ser humano precisa sair da inércia e conscientizar-se de que é parte do ambiente e que este mesmo ambiente é de todos e necessita estar saudável para o bem comum.

A figura 2 mostra um registro fotográfico em que observa-se grade concentração de fumaças proveniente de práticas de queimadas no entorno da escola.

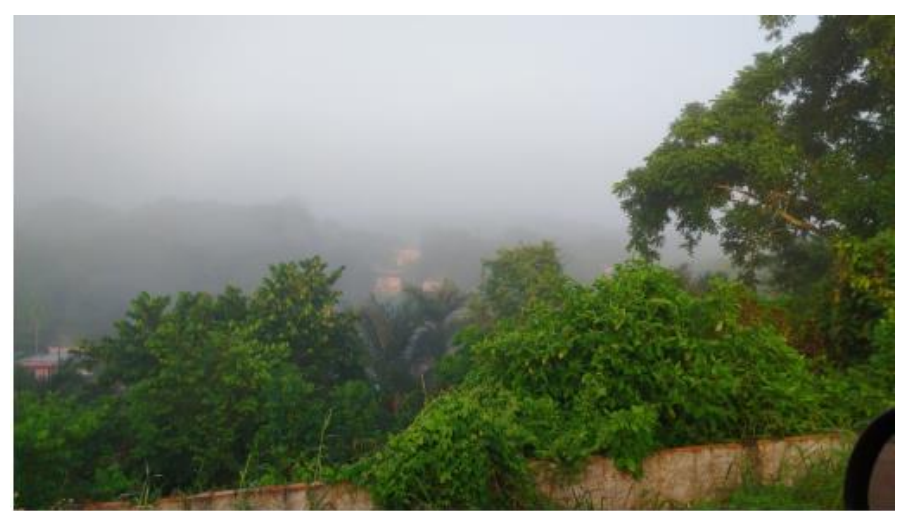

Figura 2: Visão da rua nova Republica, onde se localiza a Escola. Fonte: Autores, (2017).

Outrossim, foram desenvolvidas práticas pedagógicas interdisciplinando a educação ambiental. E como essa reflexão ambiental vai buscar soluções na sensibilização, consciência e conservação ambiental no contexto escolar por meio das práticas pedagógicas?

\section{III.4 COLETA DE DADOS}

Quanto às coletas de dados foram realizadas por meio de aplicação de questionários da pesquisa, realizados pela pesquisadora, não ocorrendo interferências nas respostas e na construção dos desenhos conforme a percepção ambiental dos alunos.

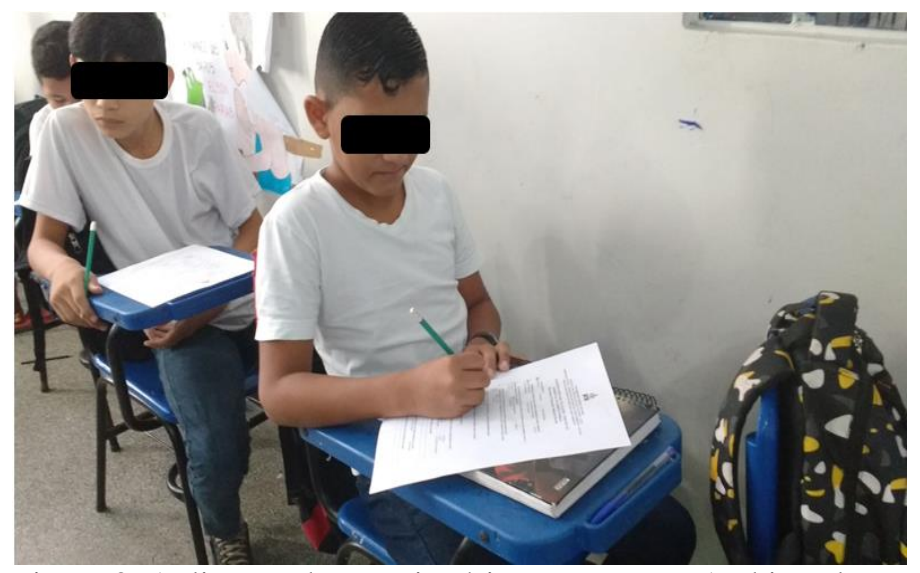

Figura 3: Aplicação do questionário - Percepção Ambiental. Fonte: Autores, (2017). 
Quanto a efetivação da pesquisa foram desenvolvido in loco, no primeiro momento realizou-se palestra expositiva, dialogada e contextualizada com temáticas relacionada à relevância da conscientização e conservação Educação Ambiental e ao combate a redução dos índices de queimadas.

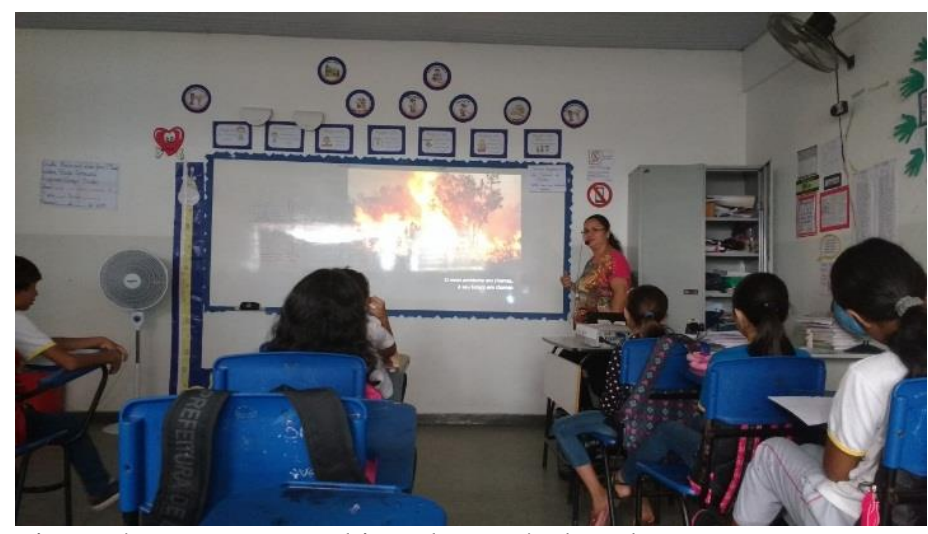

Figura 4: Percepção ambiental através de palestras.

Fonte: Autores, (2017).

No segundo momento Palestra expositivas e dialogadas e contextualizadas de Conscientização e Prevenção e Controle de queimadas e solicitação de mudas aos alunos para distribuição junto à comunidade. Foram confeccionados cartazes para exposição sobre combate e redução dos índices de queimadas e conscientização para o cuidado com o meio ambiente efetivados em sala de aula, para exposição durante a caminhada na comunidade ao entorno da escola.

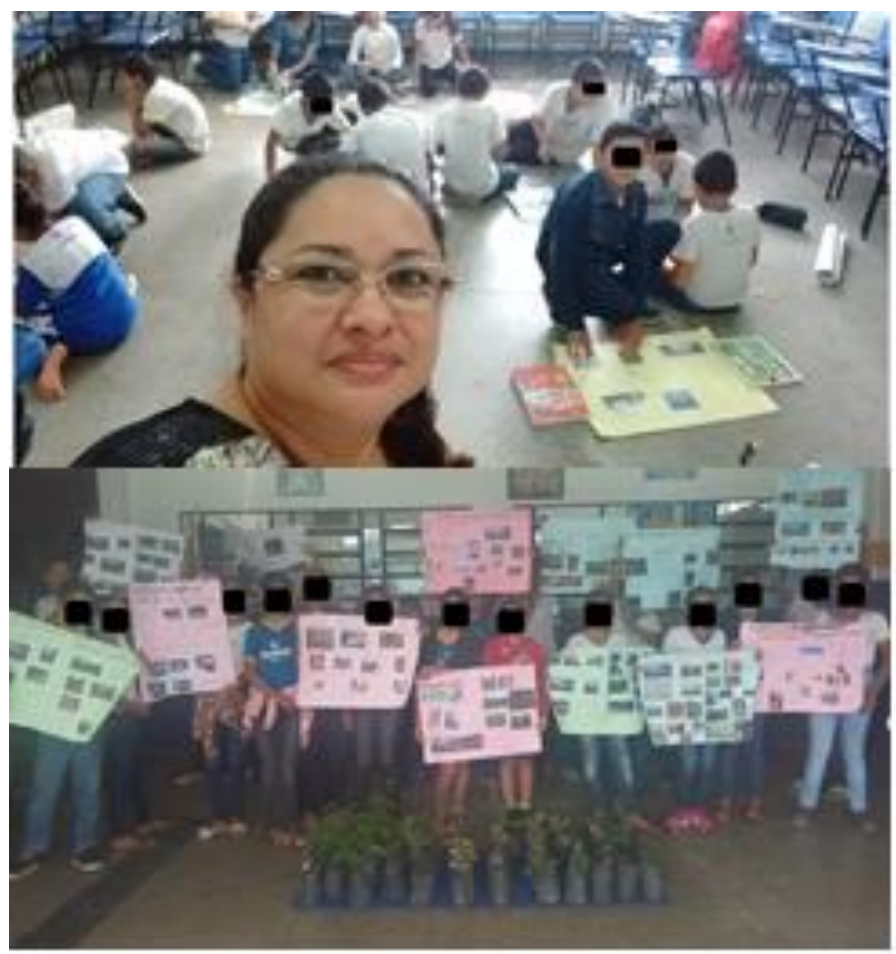

Figura 5: Percepção ambiental através da criação de cartazes. Fonte: Autores, (2017).

No terceiro momento apresentação de vídeos referentes a Prevenção e Controle de queimadas. Organização e cuidado na caminhada que será desenvolvida coma comunidade no entorno da escola e distribuição de mudas aos alunos e para entregarem aos comunitários do entorno da escola.

No quarto momento foi realizado um oficina de desenho livres relacionados ao meios ambiente, onde os alunos expressaram através das criações ilustrativas sobre a percepção ambiental adquirida.

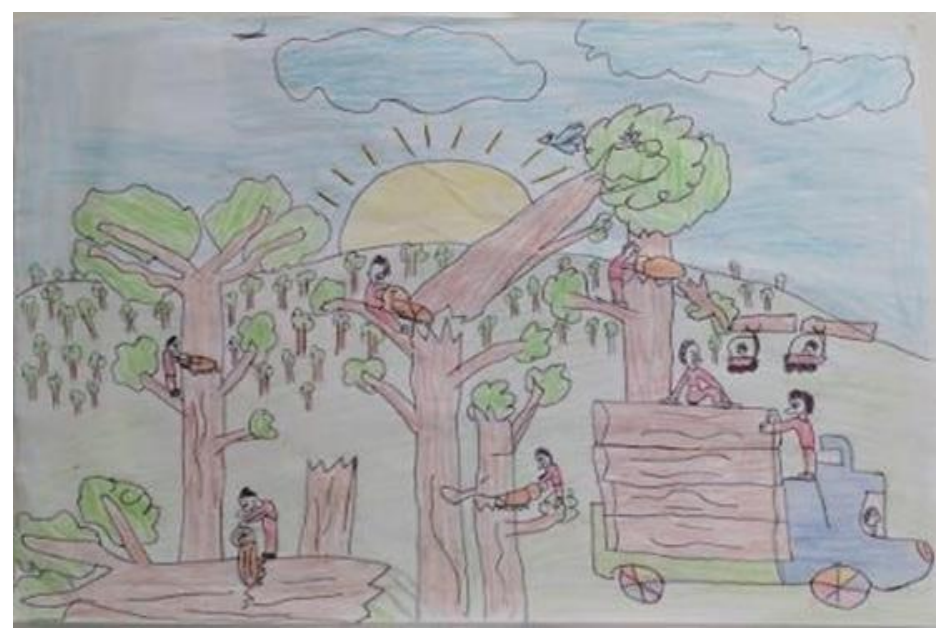

Figura 6: Percepção ambiental na visão de um aluno do ensino Fundamental I de 12 anos, mostra a extração madeireira comercial ilegal.

Fonte: Autores, (2017).

No quinto momento realização da caminhada junto com os alunos para exposição dos cartazes de cunho ambiental e entrega de mudas aos comunitários.

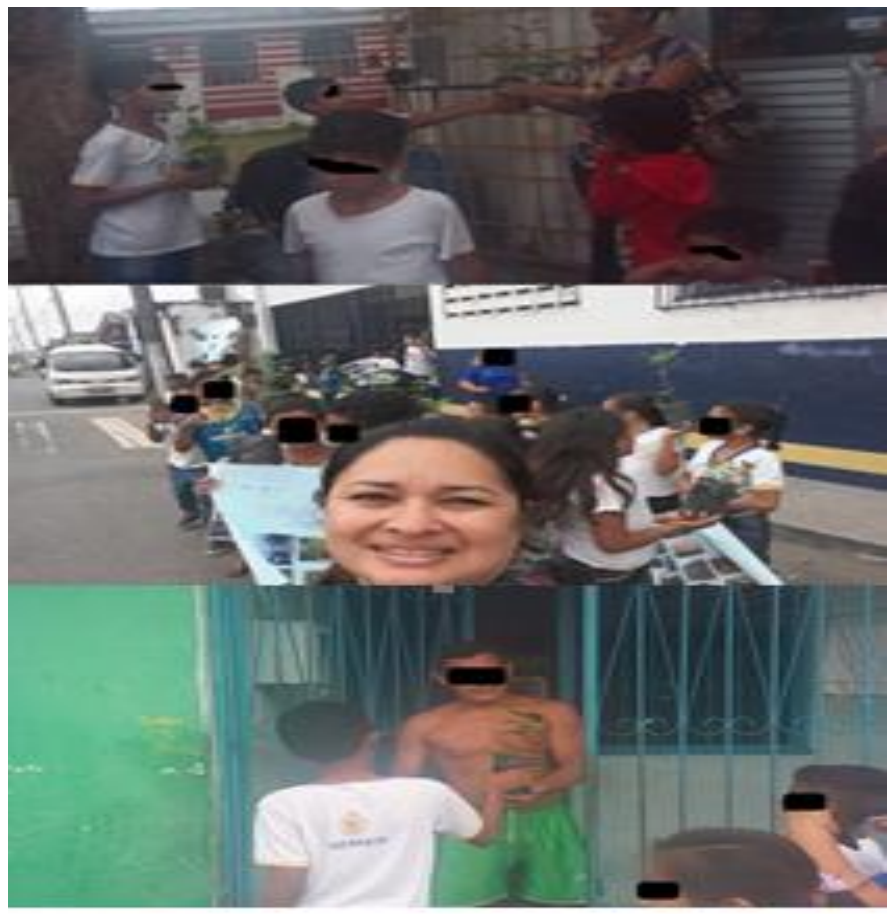

Figura 7: Distribuição de mudas a comunidade no entorno da escola.

Fonte: Autores, (2017).

Quantos aos recursos necessários foram utilizados:

$\checkmark$ Humanos: Professores, Alunos, Funcionários e Comunidade.

$\checkmark$ Materiais: foram utilizados Livros Didáticos, e Paradidáticos, Quadro Branco, lápis, canetas, pinceis hidrocor, Computador, Data-show, Papelaria (cartolina), Revistas, Jornais, CD's / DVD's.

Realização da atividade sempre na coletividade e efetivação quanto à mediação da atividade desenvolvida com intuito de despertar a conscientização no combate e redução dos índices de queimadas.

O professor sendo o mediador escriba. 


\section{RESULTADOS E DISCUSSÕES}

No que tange a análise dos dados realizou-se inicialmente aplicação do primeiro questionário para averiguar o nível de conhecimentos dos alunos quanto a temática Meio Ambiente, posteriormente iniciou-se uma intervenção por meio de práticas pedagógicas tais como palestras sobre Conscientização, Sensibilização e Preservação do Meio Ambiente, oficina de desenhos (voltadas ao meio ambiente) após a intervenção pedagógica efetivar-se aplicação do segundo questionários de pesquisa com as mesmas variáveis. Apresentando-se em dois momentos um sem intervenção pedagógica e outro com intervenção pedagógica.

Quanto à aplicação do questionário da pesquisa não houve interferências na percepção dos alunos em relação ao meio ambiente quanto suas respostas e no que concerne aos desenhos às temáticas mais abordadas foram "Queimadas e Desmatamentos", haja vista ser uma inquietação principalmente no fim da tarde, pois existe uma prática comum junto à comunidade no entorno da escola. $\mathrm{O}$ recolhimento do material ocorreu no mesmo dia para que não houvesse perda do material e idoneidade na pesquisa.

No gráfico da figura 8 , mostra a identificação dos gêneros dos pesquisados, foram pesquisados 36 alunos, 30 alunas totalizando 66 alunos, 1 professor e 7 professoras.

\section{Qual seu Gênero?}

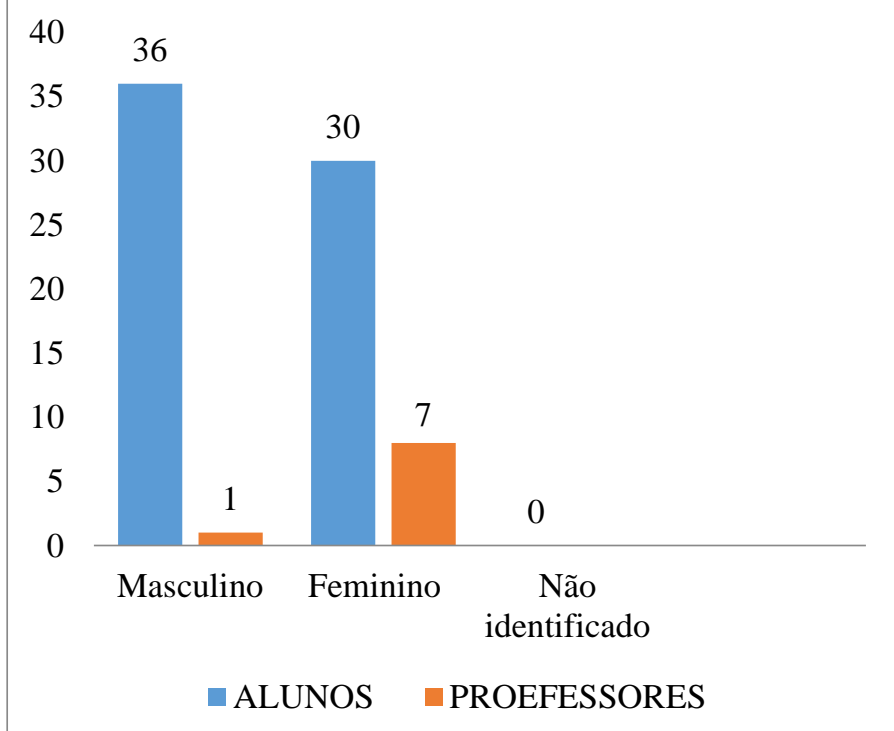

Figura 8:Identificação do gênero dos pesquisados.

Fonte: Autores, (2017).

O gráfico da figura 9 mostra a Classificação do interesse sobre assuntos relacionados ao Meio Ambiente. Sem intervenção pedagógica os resultados apresentam-se: 18 alunos com muito interesse, 8 alunos razoavelmente interessado, 6 alunos não sabem responder e 14 alunos não apresentam nenhum interesse.

Com intervenção pedagógica observa-se que houve um aumento significativo de 49 alunos demonstrando muito interesse nos assuntos relacionados ao meio ambiente.

Quanto aos professores 3 responderam muito interessado, 3 raramente interessado, 1 não sabia responder e 1 pouco interessado.

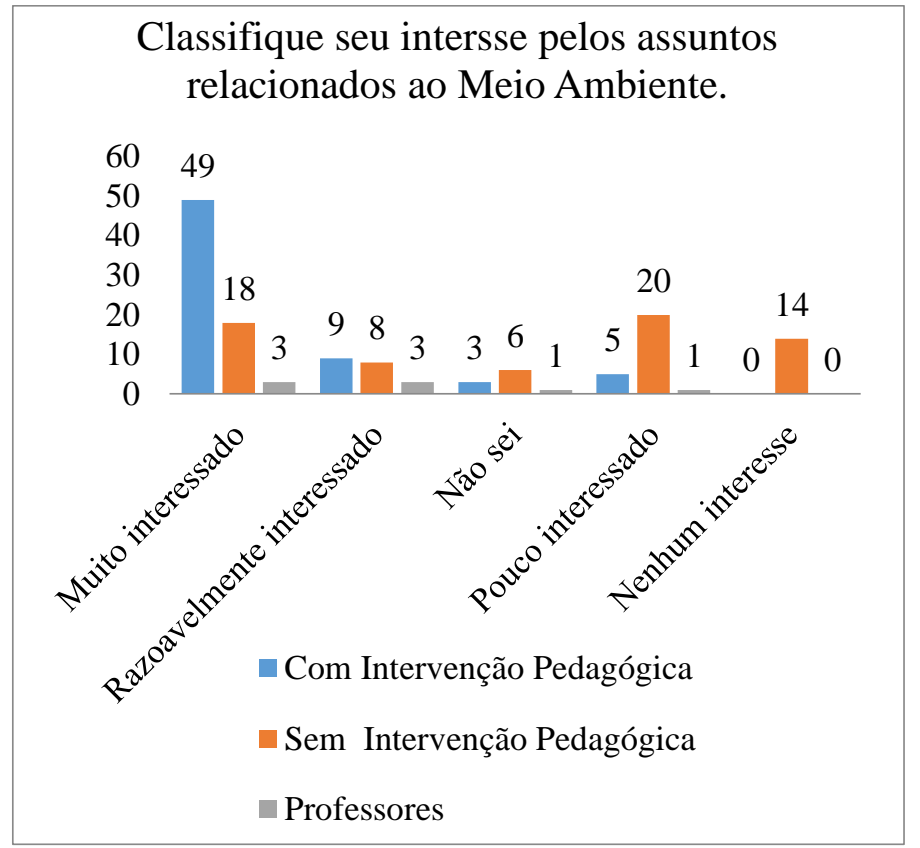

Figura 9: Classificação do interesse sobre assuntos relacionados ao Meio Ambiente.

Fonte: Autores, (2017).

O gráfico da figura 10 mostra a frequiência da abordagem sobre Meio Ambiente em sala de aula.

Na sua escola em sala de aula, o professor (a) aborda com que frequência sobre os assuntos ligados ao Meio Ambiente?

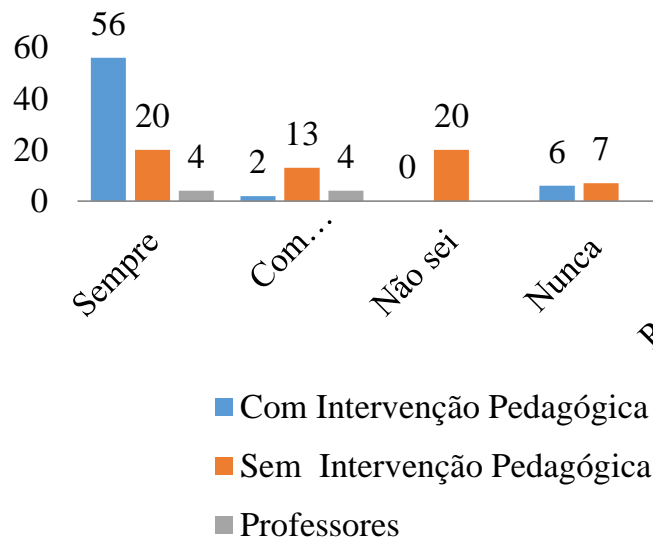

Figura 10: Frequência da abordagem sobre Meio Ambiente em sala de aula.

Fonte: Autores, (2017).

Na percepção dos alunos sem a intervenção pedagógica pode-se perceber que 20 alunos responderam que sempre, 13 alunos com alguma frequiência 20 alunos não sabiam, 7 alunos responderam que nunca e 6 alunos disseram que raramente. Com a intervenção pedagógica 56 alunos responderam que sempre, 2 alunos com pouca frequiência, 0 alunos não sabiam responder, 6 alunos responderam nunca e 6 alunos raramente. Quanto aos professores 4 responderam que sempre e 4 com alguma freqüência.

O gráfico da figura 11 apresenta o cuidado ao desligar as luzes e condicionador de ar ao sair da sala de aula. Na percepção dos alunos sem a intervenção pedagógica pode-se perceber que 8 alunos desligam as luzes e o condicionador de ar, 13 alunos responderam que não possuem esse habito, 33 alunos 
somente as vezes e 12 alunos não souberam responder. Quanto aos professores 8 desligam as luzes ao saírem da sala de aula.

Você desliga as luzes e o condicionador de ar ao sair da sala da sala de aula?

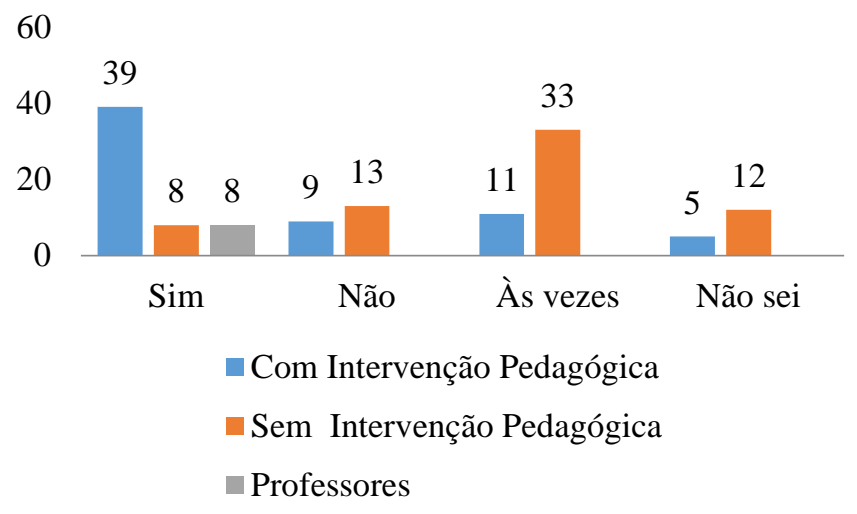

Figura 11: Cuidado ao desligar as luzes e condicionador de ar ao sair da sala de aula.

Fonte: Autores, (2017).

O gráfico da figura 12 mostra o Cuidado quanto ao desperdiço de água sem a intervenção pedagógica apresentou-se 26 alunos não se preocupavam em fechar a torneira da pia do banheiro, 19 alunos responderam não fechavam, 20 alunos às vezes se importavam e 1 aluno respondeu não sei.

Com intervenção pedagógica 57 alunos afirmaram que fecham a torneira, 1 aluno disse não, 7 alunos responderem as vezes e 1 aluno não sei. Quanto aos professores os 8 responderam que fecham a torneira para evitar o desperdiço de água.

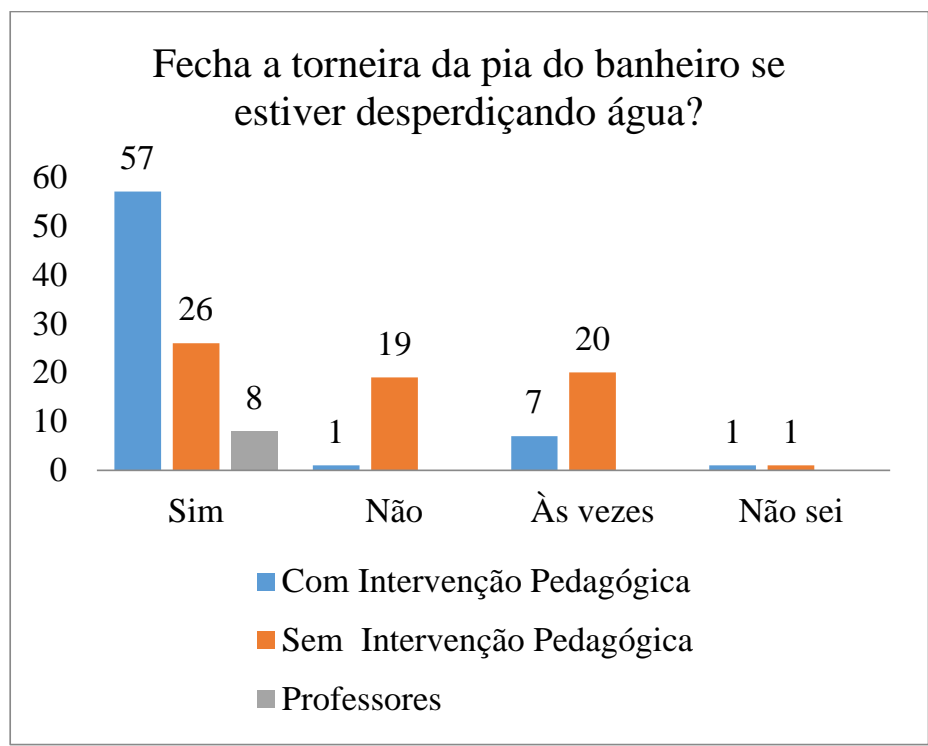

Figura 12: Cuidado quanto ao desperdiço de água.

Fonte: Autores, (2017).

O gráfico da figura 13, mostra o Cuidado quanto colocar a o papel não utilizado na lixeira, observa-se que sem a intervenção pedagógica 22 alunos responderam que descartam o papel na lixeira, 18 alunos disseram não, 14 alunos responderam às vezes e 12 alunos não souberam responder. Com intervenção pedagógica 49 alunos descartam o papel na lixeira, 4 alunos responderam que não, 13 alunos as vezes e 12 alunos não souberam responder. Quanto aos professores 8 descartam na lixeira.
Em sala de aula você coloca o papel que não utilizara mais na lixeira?

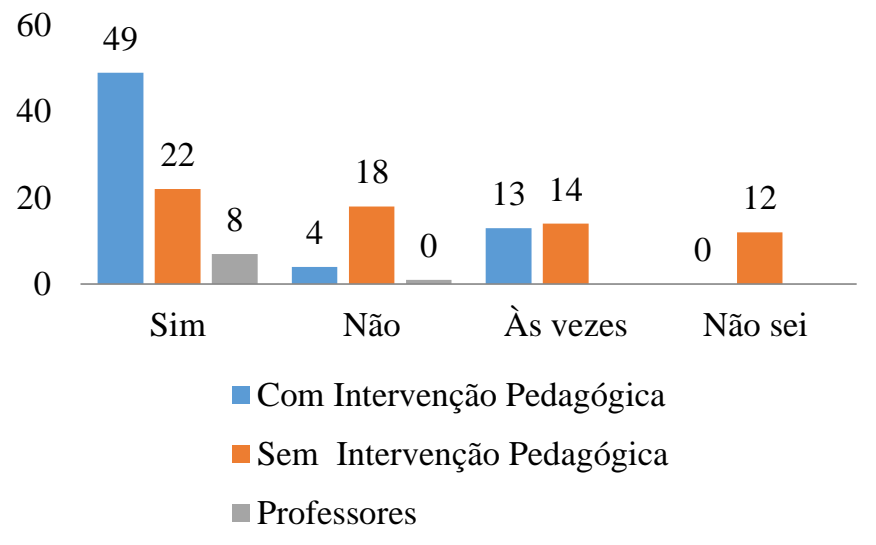

Figura 13: Cuidado quanto colocar o papel não utilizado na lixeira.

Fonte: Autores, (2017).

O gráfico da figura 14 quanto a Verificação quanto à existência de lixeira de coleta seletiva na escola, no primeiro momento sem intervenção foi possível constatar que 55 alunos perceberam a existência de lixeira seletiva na escola e 11 alunos não souberam responder. Com a intervenção pedagógica subiu para 63 alunos e diminuiu para 3 alunos que não souberam responder.

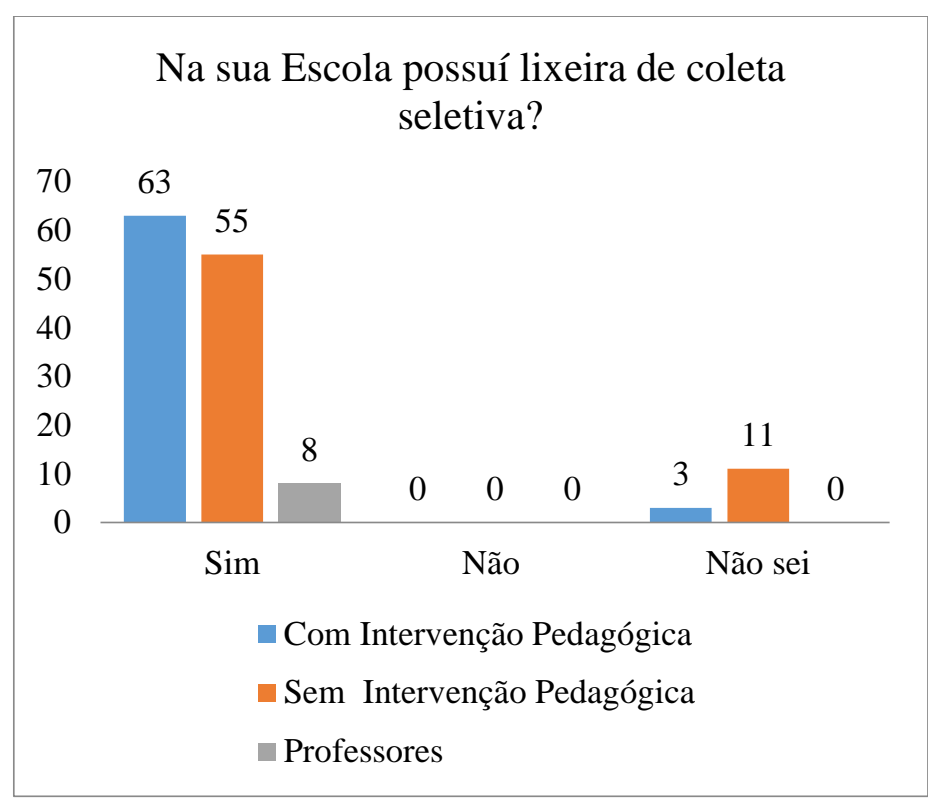

Figura 14: Verificação quanto a existência de lixeira de coleta seletiva na escola.

Fonte: Autores, (2017).

No gráfico da figura 15 observa-se a Verificação de abordagem sobre o Meio Ambiente quanto sua interdiscipliridade, observa-se que sem intervenção não havia uma expressividade quanto à compreensão de interdisciplinaridade entre os componentes curriculares e o que mais apresentou a temática meio ambiente foram o componente curricular Ciências e posterior a intervenção pedagógica houve uma percepção maior sobre meio ambiente com relação aos demais componentes curriculares sendo que 41 alunos responderam que percebem essa abordagem em Português, 55 alunos em Ciências, 35 alunos em História, 41 alunos em Matemática, 38 alunos em Geografia, 19 alunos em Educação 
Física, 18 alunos em Ensino Religioso, 18 alunos em Arte e 27 alunos em todos os componentes curriculares.

Quanto aos professores a percepção interdisciplinar foram distribuídas em 3 em Português, 3 em Ciências, 2 em História, 1 em Matemática, 5 em Geografia, 1 em Educação Física, 1 em Ensino Religioso, 3 em Arte 1em todos os componentes curriculares.

Outro ponto relevante Quanto à abordagem indagou-se qual o assunto que mais chama atenção. Na concepção de alunos e professores destacam-se:

Preservação do Meio Ambiente; cuidado com o ambiente no qual o sujeito está inserido; Poluição em geral (ar, solo, água, energia); A importância da água e o uso correto da água; Paisagem natural e modificada; Reciclagem, reutilização, reaproveitamento.

Em qual Matéria seu professor (a) aborda os assuntos relacionados ao Meio Ambiente?

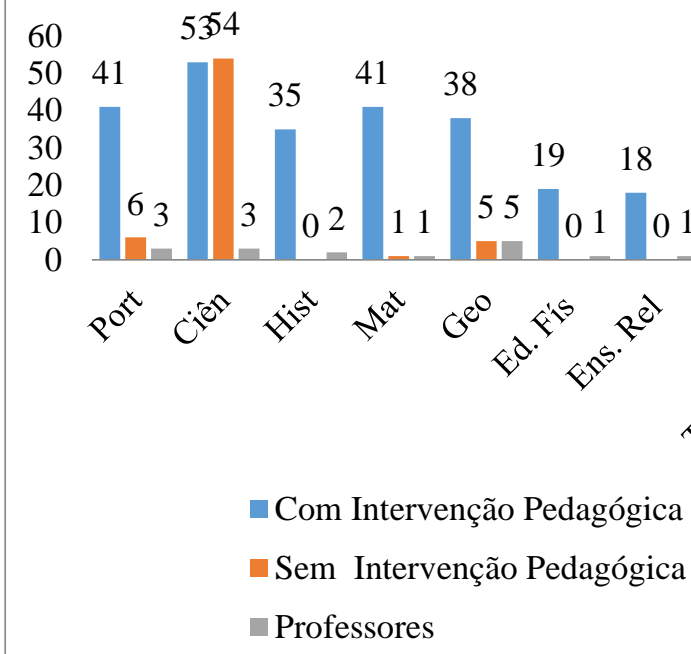

Figura 15: Verificação de abordagem sobre o Meio Ambiente quanto sua interdiscipliridade.

Fonte: Autores, (2017). âmbito familiar.

A figura 16 mostra o Panorama da Educação Ambiental

\section{Você considera importante abordar sobre} meio ambiente em casa?

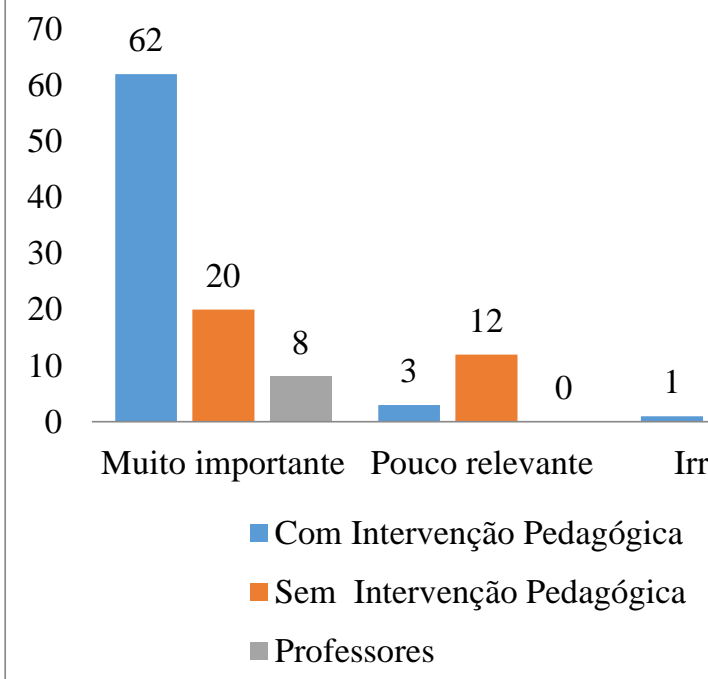

Figura16: A relevância da abordagem sobre meio ambiente em casa.

Fonte: Autores, (2017).
O gráfico da figura 16 mostra a relevância da abordagem sobre meio ambiente em casa apresenta sem intervenção pedagógica 20 alunos consideram muito importante falar sobre meio ambiente em casa, 12 alunos consideram pouco relevante, 34 alunos consideram irrelevante abordar sobre meio ambiente em casa. Com a intervenção pedagógica ocorreu um acréscimo de 62 alunos que consideram muito importante abordar sobre o meio ambiente em casa, 3 alunos consideram pouco relevante e 1 aluno considera irrelevante. Quanto aos professores os 8 consideram muito importante falar sobre o meio ambiente em casa.

Outras questões relevantes foram sobre a abordagem de falar de meio ambiente em casa. Entre professores e alunos podemos destacar:

"Para adquiri consciência e importância de cuidar"; "Acredito que tudo tem que ter o começo na família"; "Por conta do desperdício e consequentemente o gasto indevido"; "Para que todos da família estejam sempre conscientes a importância de preservar o meio ambiente" "Para que todos os membros da família estejam sempre conscientes da importância de preservar o meio ambiente"; e Porque a educação começa em casa".

No gráfico da figura 17 , observa-se o Cuidado com o desperdiço de água em casa sem intervenção pedagógica 23 alunos se preocupavam com a torneira aberta ou pingando, 8 alunos não se preocupavam e 35 alunos responderam as vezes. E aos professores todos os 8 tinham essa preocupação em fechar a torneira da pia do banheiro.

\section{Você fecha a torneira da pia do banheiro ou da cozinha sua casa se encontrar ligada ou pingando?}

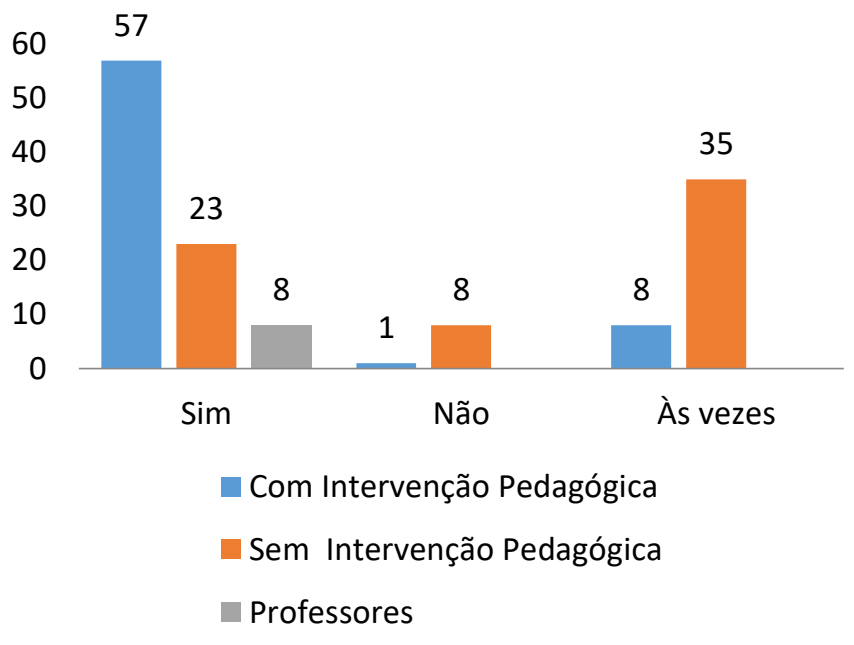

Figura 17: Cuidado como desperdiço de água em casa. Fonte: Autores, (2017).

O gráfico da figura 18 mostra a economia de energia elétrica em casa, sem intervenção pedagógica observam-se que 17 alunos responderam sim, 27 alunos responderam não e 22 alunos responderam às vezes há essa preocupação com o ato de desligar a energia elétrica ao entrar e sair dos cômodos da cassa. Com a intervenção pedagógica 51 alunos responderam que desligam a energia elétrica sempre que saem dos cômodos da casa, 5 alunos responderam que não, 10 alunos as vezes desligam as luzes dos cômodos de sua casa. Quanto aos professores os 8 desligam a energia elétrica sempre que entram ou saem dos cômodos de sua casa. 
Você desliga a energia elétrica sempre que entra ou saí dos cômodos de sua casa?

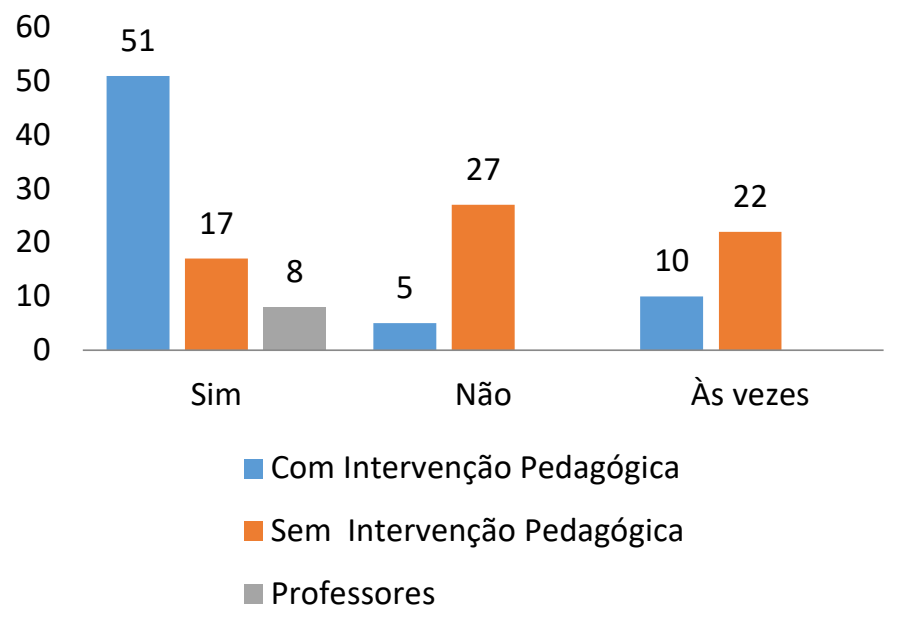

Figura 18: Economia de energia elétrica em casa.

Fonte: Autores, (2017).

O gráfico da figura 19 mostra a seleção de lixo por tipo.

\section{Quanto ao lixo, você separa o lixo por tipo exemplo o plástico, vidro, papel, orgânico e metal?}

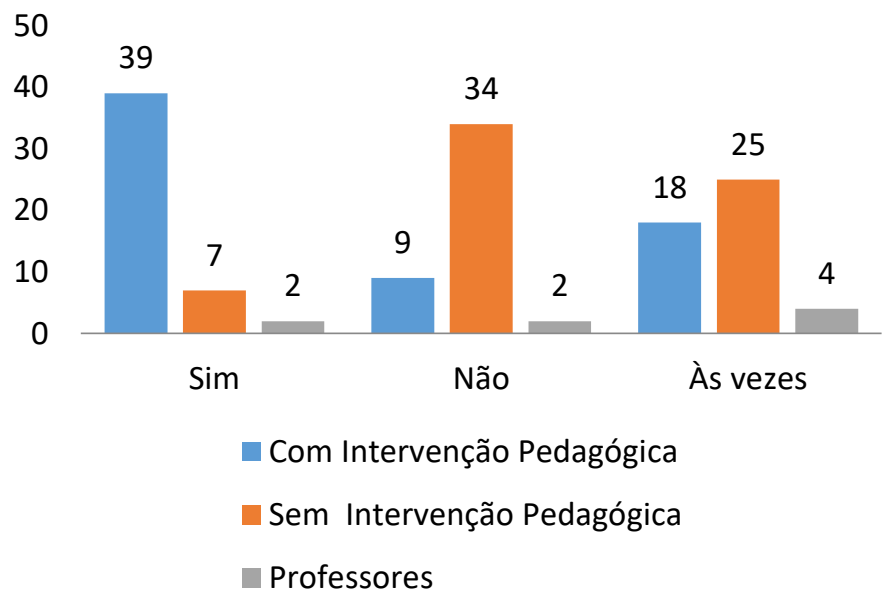

Figura 19: Seleção de lixo por tipo.

Fonte: Autores, (2017).

Nesse gráfico observa-se que sem intervenção pedagógica 7 alunos apresentam essa preocupação quanto a separação do lixo, 34 alunos não se preocupam com a seleção de lixo e 25 alunos somente as vezes apresentavam esse preocupação. Com intervenção pedagógica houve um aumento significativo onde 39 alunos que separa o lixo por tipo, 9 alunos continuaram a não separar e 18 alunos somente as vezes.

Quanto aos professores 2 separam o lixo, 2 não separam o lixo e 4 responderam as vezes separam o lixo.

O gráfico da figura 20 mostra o cuidado com o lixo residencial e como sua trata o lixo sem intervenção 20 alunos juntam tudo e Poe na lixeira, 5 alunos separa a comida, 3 alunos separa plástico e papel. Com intervenção pedagógica 35 alunos juntam tudo e põe na lixeira, 15 alunos separam a comida e 16 alunos separam plástico e papel e nenhum jogam no quintal.

\section{O que sua família faz com o lixo da casa?}

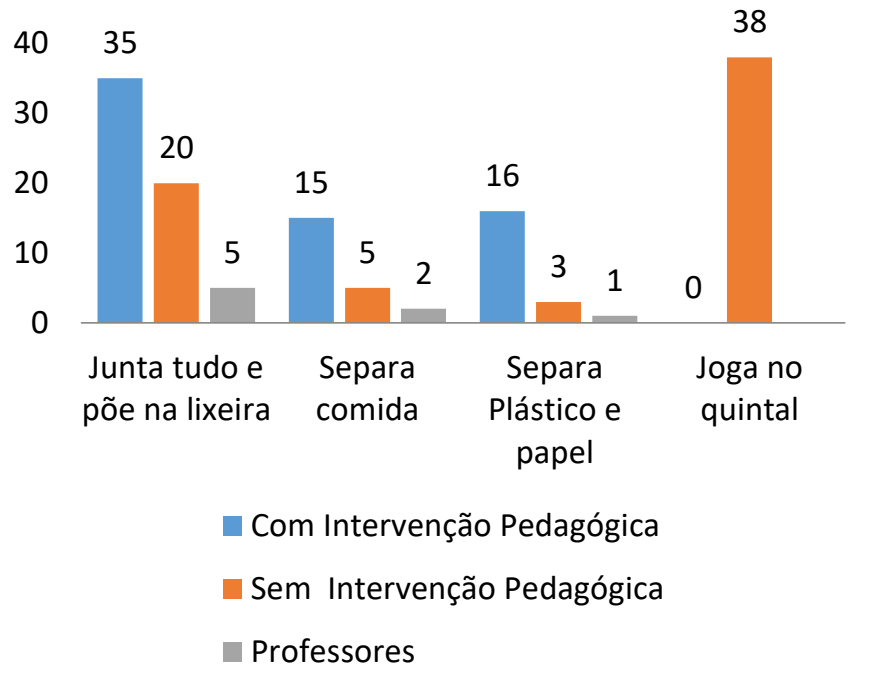

Figura 20: Cuidado com o lixo residencial.

Fonte: Autores, (2017).

O gráfico da figura 21 mostra a relevância da abordagem sobre o meio ambiente em casa, sem intervenção pedagógica 19 alunos responderam que muito importante essa abordagem ambiental, 7 alunos consideravam pouco relevante e 40 alunos consideravam irrelevante a abordagem ambiental no âmbito familiar.

Com a intervenção pedagógica 53 alunos consideram muito importante abordagem ambiental no contexto familiar, 10 alunos consideram relevante e 3 alunos consideram irrelevante houve uma diminuição significativa quanto essa variável. No que concerne aos professores os 8 consideram muito importante tratar dessa temática no ambiente familiar.

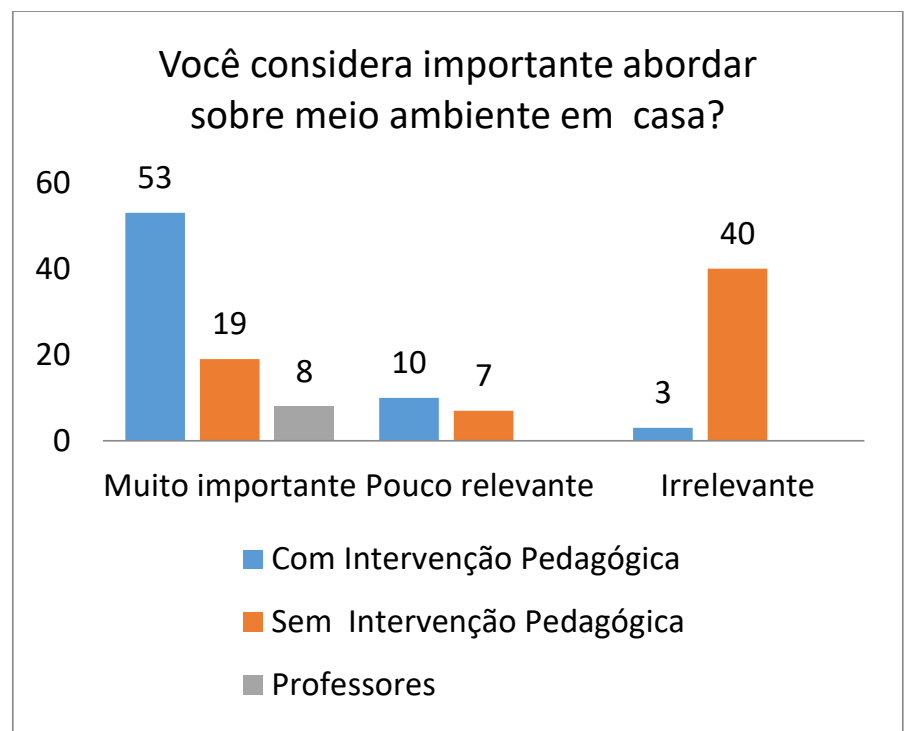

Figura 21: Relevância da abordagem sobre o Meio Ambiente em casa.

Fonte: Autores, (2017).

O gráfico da figura 22 mostra a verificação de arborização sem intervenção pedagógica podemos verificar que 16 alunos responderam de sim plantaram uma árvore, e 50 alunos responderam que não plantaram uma árvore.

Dentre os oitos professores 7 responderam que já plantaram uma arvore e 1 respondeu que não plantou uma árvore. 


\section{Você já plantou uma árvore?}

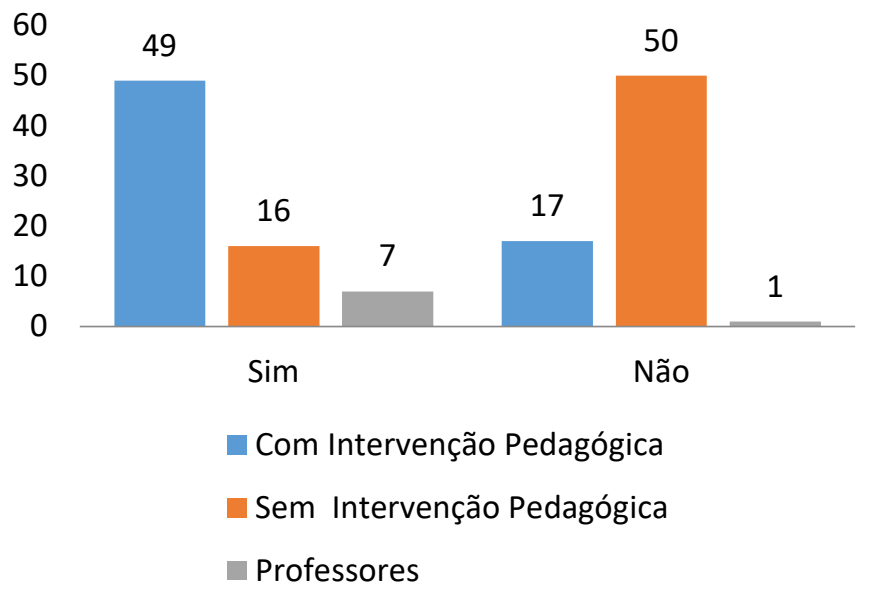

Figura 22: Verificação de Arborização.

Fonte: Autores, (2017).

O gráfico da figura 23 mostra como é feita a limpeza do quintal ou da calçada no ambiente residencial sem intervenção pedagógica observa-se que 23 alunos queimam o lixo, 20 alunos ensacam o lixo, 13 alunos jogando o lixo na rua e 10 alunos colocando no tambor.com intervenção pedagógica 8 alunos responderam que queimam o lixo, 48 alunos ensacam o lixo, 3 alunos jogam o lixo na rua e 7 colocam no tambor. Quanto aos professores os 8 ensacam o lixo.

\section{Como é feita a limpeza do quintal ou calçada da sua casa?}

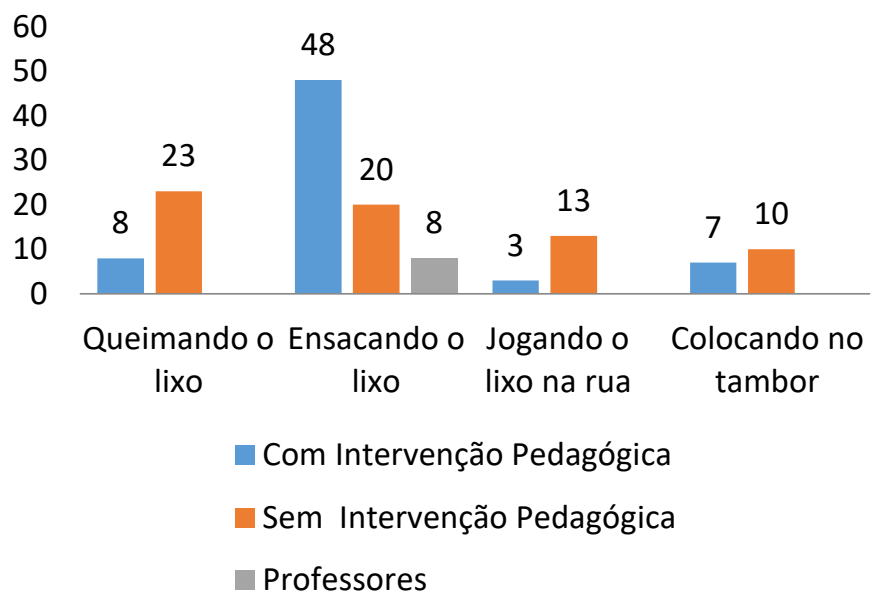

Figura 23: Tipo de realização de limpeza do quintal e da calçada de sua residência.

Fonte: Autores, (2017).

Em uma das variáveis subjetivas foram solicitadas que escrevessem três coisas que fariam para melhorar o meio ambiente, dentre as quais podemos destacar as 13 melhores respostas.

"Não jogar o lixo no rio";

$\checkmark$ "Não queimar mais o lixo de casa ou as folhas";

$\checkmark$ "Ter cuidado para com o meio ambiente, usando produtos que não agride o meio ambiente";

$\checkmark$ "Sensibilização para a educação familiar para o cuidado com o meio ambiente; "Uso de produtos recicláveis";

$\checkmark$ " Procurar trabalhar a conscientização para coleta seletiva, pois existem poucos pontos coleta seletiva";

$\checkmark$ "Separaria o lixo corretamente"; $\checkmark \quad$ "Reeducaria o povo para educação ambiental";

$\checkmark$ "Preservar das nascentes não retirando as matas ciliares";

$\checkmark \quad$ "Plantar mais árvores";

$\checkmark$ "Enfatizar a importância do meio ambiente";

$\checkmark$ " Reaproveitamento de água por meio de captação, evitando o desperdício de água tratada"; e

$\checkmark$ "Realizar o descarte correto de pilhas e baterias".

Pode-se perceber que houve um aumento significativo de conscientização com a temática em questão por meio das práticas pedagógicas aplicadas aos alunos. Desta forma a educação constitui uma arena, um espaço social que abriga uma diversidade de práticas de formação de sujeitos [4].

\section{CONCLUSÃO}

A educação ambiental apresenta-se como um instrumento muito relevante para mudanças de atitudes. A partir desse contexto as práticas pedagógicas, formais, desempenham a singularidade dos sujeitos quanto sua construção enquanto cidadãos capazes de participar de tomadas de decisões, reconhecer os problemas socioambientais atuais para os quais busca-se soluções individuais ou coletivas para o desenvolvimento humano na construção da cidadania por meio de uma sensível percepção dos ambientes na qual os sujeitos estão inseridos.

Buscou-se Inferir sobre as percepções da educação ambiental como experiência integradora por meio das práticas pedagógica. Buscando uma reflexão perceptiva sobre a relevância da educação ambiental como experiência integradora por meio de suas práticas pedagógica. Despertando a sensibilização, conscientização e conservação para o cuidado com o meio ambiente. A educação escolar é uma educação sistemática (formal) e intencional (não-formal) no processo de interação com a realidade, cuja sua finalidade é de colaborar na formação do educando na sua totalidade, referir-se a sua consciência, ao seu caráter e o exercício para cidadania. A prática pedagógica Ambiental, torna-se cada vez mais relevante no âmbito escolar e comunidade, para um despertar crítico e consciente de modo formal visando a relevância da educação ambiental na preparação do aluno para a construção de um discurso crítico dos fatos que ocorrem em seu cotidiano, e apropriando-se desta prática pedagógica como uma ferramenta de ensino libertadora na formação de sujeitos com pensamento crítico e reflexivo.

Concernentemente formar alunos que se desenvolvam nas diferentes habilidades e competências necessárias para que possam se inserir no meio e ser parte integral ao convívio social. Nesse contexto a educação ambiental apresenta-se como instrumento de emancipação e não como instrumento de alienação.

Nessa perspectiva, afirma-se a relevância dos atores com a educação ambiental por meio de práticas pedagógicas para a conscientização, sensibilização e conservação. De modo que é na escola que se oportuniza aos alunos uma formação integral e de qualidade, para o desenvolvimento da transformação social e ambiental na busca de valores que conduzam a uma convivência harmônica com o meio ambiente.

Quanto aos Resultados obtidos com a pesquisa sugerese adesão no calendário pedagógico escolar para sua efetivação utilizando-se das práticas pedagógicas de ensino voltadas a Educação Ambiental que contemple principalmente alunos e comunidade, para um despertar crítico e consciente de modo formal visando a relevância da educação ambiental para transformação social 
Que seja realizado a I Mostra das Práticas Pedagógicas da Escola Padre João D'Vries voltadas a Educação Ambiental com intuito de apresentar os novos projetos despertados a partir dessa pesquisa.

\section{AGRADECIMENTOS}

Ao PPGCMA/ICEN da Universidade Federal do Pará (UFPA), ao Instituto de Tecnologia e Educação Galileo da Amazônia (ITEGAM) e a Escola Municipal Padre João D’Vries.

\section{REFERÊNCIAS}

B. G. Adams, "A importância da Lei 9.795/99 e das diretrizes curriculares nacionais da Educação Ambiental para docentes," Monografias Ambientais, vol. 10, pp. 2148-2157, 2013.

P. d. R.-C. Civil, "Política Nacional de Educação Ambiental-Lei 9795/99," 1999.

C. Marcatto, "Educação ambiental: conceitos e princípios," Belo Horizonte: FEAM, vol. 1, 2002.

J. S. Quintas, "Educação no processo de gestão ambiental: uma proposta de educação ambiental transformadora e emancipatória," Identidades da educação ambiental brasileira. Brasília: Ministério do Meio Ambiente, pp. 113-140, 2004.

P. Jacobi, "Educação ambiental, cidadania e sustentabilidade," Cadernos de pesquisa, vol. 118, pp. 189-205, 2003.

P. R. Jacobi, "Educação ambiental: o desafio da construção de um pensamento crítico, complexo e reflexivo," Educação e pesquisa, vol. 31, 2005.

P. C. N. para o Ensino, "Médio," Brasília (DF), 1998.

S. Czapski, A implantação da educação ambiental no Brasil: Coordenação de Educação Ambiental, Ministério da Educação e do Desporto, 1998.

E. Morin, O pensar complexo: Edgar Morin e a crise da modernidade: Editora Garamond, 1999.

E. Morin, "Os desafios da complexidade," Morin E, organizador. A religação dos saberes. O desafio do século XXI. Rio de Janeiro: Editora Bertrand Brasil, pp. 559-67, 2001.

E. Morin, "A necessidade de um pensamento complexo," Representação e complexidade. Rio de Janeiro: Garamond, pp. 69-77, 2003.

G. Foladori, "Ecologia, capital e cultura: racionalidade ambiental, democracia participativa e desenvolvimento sustentável," Ambiente \& Sociedade, pp. 169-173, 2000.

E. Leff, "Ecologia, capital e cultura: racionalidade ambiental, democracia participativa e desenvolvimento sustentável. FURB, São Paulo Blumenau, Brasil," Coleç. Soc. Ambiente, vol. 5, 2000.

[14] R. S. Fernandes, V. J. d. Souza, V. B. Pelissari, and S. T. Fernandes, "Uso da percepção ambiental como instrumento de gestão em aplicações ligadas às áreas educacional, social e ambiental," Encontro Nacional de Pós-Graduação e Pesquissa em Ambiente e Sociedade, vol. 2, pp. 1-15, 2004.

[15] A. A. Gonçalves, M. E. O. Lima, and M. R. Marques, "A percepção e educação ambiental com alunos do ensino fundamental," ed: Centro Universitário de Belo Horizonte, Departamento de Ciências Biológicas Belo Horizonte, MG, 2009.

[16] G. dos Santos Rodrigues, C. A. Nahum, D. d. S. B. Brasil, T. R. Felipe, V. dos Santos Rodrigues, and P. F. R. Ramkeerat, "Environmental Education: Pedagogical Practices of Awareness in Combating and Reducing Burned Indices," 2016.

[17] L. A. S. BARBOSA, "Educação Ambiental e Linguagem: o uso do livro paradidático interativo como proposta pedagógica para despertar a sensibilização ambiental," 2014.

[18] G. C. Melazo, "Percepção ambiental e educação ambiental: uma reflexão sobre as relações interpessoais e ambientais no espaço urbano," Olhares \& Trilhas, 2005.

[19] C. A. Machado, "Desmatamentos e queimadas na região norte do estado do tocantins," Caminhos de Geografia, vol. 13, 2012.

[20] H. C. Callai, "O meio ambiente no ensino fundamental," Terra Livre, pp. 09-19, 2015.

J. R. Torres, "Educação ambiental críticotransformadora e abordagem temática freireana," 2010 .

[22] M. Reigota, O que é educação ambiental: Brasiliense, 2017.

[23] Z. Jófili, "Piaget, Vygotsky, Freire e a construção do conhecimento na escola," Educação: teorias e práticas, vol. 2, pp. 191-208, 2002.

[24] A. Gaspar, "A educação formal e a educação informal em ciências," Massarani (Luisa), Moreira (Ildeu de Castro), Brito (Fátima). Ciência e público. Local: Editora UFRJ, pp. 171-183, 2002.

[25] R. d. A. Neves and M. F. Damiani, "Vygotsky e as teorias da aprendizagem," 2006.

[26] J. La Rosa, Psicologia e educação: o significado do aprender: Edipucrs, 2001.

A. M. B. Baeta, A. Soffiati, C. F. B. Loureiro, G. F. d. C. Lima, L. A. Passos, M. Sorretino, et al., Educaçäo ambiental: repensando o espaço da cidadania: Cortez, 2002. 
[28] Instituto Nacional de Meteorologia - INMET, 2017. -

Índice de Inflamabilidade de Nesterov

http://www.inmet.gov.br/portal/index.php?r=aplicacoes/in

diceInflamabilidade - Acesso em 01/06/2017 